\title{
PELATIHAN PEMERIKSAAN TAJAM PENGLIHATAN \\ PADA SISWA KELAS 5 SD GEDONGAN I, COLOMADU, KARANGANYAR
}

\section{EM Sutrisna, Dedy Hanwar, Peni Indrayudha, dan Tanti Azizah S \\ Fakultas Farmasi \\ Universitas Muhammadiyah Surakarta}

\section{ABSTRACTS}

Seeing is crucial aspect in life includes in the field of education. If it is not cured the reduction of sharpness of seeing/visus can affect the student ability to study. This action is done to detect this reduction early. Therefore, the eyes will not be getting worse. The research is done by training and demonstrating how to check visus. The location of the research is SD Gedongan I, Gedongan, Colomadu, Karanganayar. The 31 students are checked. The result is that there are 3 students have visus with miop. All the students can participate in this research well.

Keywords: training, visus.

\section{PENDAHULUAN}

Penglihatan merupakan salah satu faktor yang sangat penting dalam seluruh aspek kehidupan termasuk diantaranya pada proses pendidikan. Seorang siswa tanpa penglihatan yang baik akan sulit menyerap dan memahami pelajaran yang diberikan oleh gurunya dalam proses kegiatan belajar mangajar. Penurunan tajam penglihatan yang minimal mungkin tidak disadari oleh siswa tersebut karena kemampuan pemahaman siswa tersebut terhadap proses yang terjadi pada dirinya belum maksimal. Para guru juga terkadang tidak memahamai kondisi yang terjadi pada siswa tersebut. Penurunan tajam penglihatan yang ringan kalau dibiarkan akan akan berakibat pada beberapa hal: a)

kerusakan mata semakin parah; dan b) prestasi belajar anak akan menurun.

SD gedongan I terletak didusun Gedongan , desa Gedongan, kecamatan Colomadu Kabupaten Karnganyar. Lokasi tersebut berada di pinggiran wilayah Surakarta bagian barat laut. Sekolah tersebut memiliki 6 ruang kelas, 1 ruang guru, 1 aula, dan 1 ruang UKS. Pengabdian masyarakat ini dimaksudkan untuk melatih siswa kelas 5 yang berjumlah sekitar 32 orang tentang cara pemeriksaan tajam penglihatan/visus. Alasan dipilih kelas 5 karena: a) siswa kelas 5 masih 
sekolah di SD tersebut lebih dari 1 tahun; dan b) pada usia tersebut, siswa kelas 5 dianggap lebih mudah untuk dilatih.

Dengan selesainya pengabdian tersebut diharapkan siswa yang dilatih mampu memeriksa tajam penglihatan diantara sesama temannya dan pada adik kelasnya.

\section{RUMUSAN MASALAH}

Dari tinjauan pustaka dapat dibuat suatu rumusan masalah sebagai berikut: Penurunan tajam penglihatan akan mempengaruhi kemampuan melihat. Hal ini akan memnyebabkan penurunan kemampuan siswa untuk menangkap pelajaran secara visual yang pada akhirnya dapat mempengaruhi/menurunkan prestasi belajar siswa

Tujuan kegiatan pengabdian masyarakat ini adalah melakukan pemeriksaan tajam penglihatan dan melakukan pelatihan tentang cara pemeriksaan tajam penglihatan pada siswa kelas 5

Dengan selesainya pengabdian diharapkan siswa kelas 5 menjadi tahu tentang cara pemeriksaan tajam penglihatan dan dapat memeriksa dan melatih teman-temannya tentang cara pemeriksaan tajam penglihatan, sehingga penurunan tajam penlihatan yang ringan dapat dideteksi secara dini.

\section{a. Optik mata}

Mata secara optik dapat disamakan kamera fotografis biasa karena mata tersebut memiliki suatu lensa (lensa mata), lubang lensa yang berubah ubah dan sebuah retina yang dapat disamakan dengan film. Sistem mata terdiri dari humor akuous, lensa mata, humor vitreus dan retina (Guyton, 2001). Mata dibentuk untuk menerima rangsangan berkas cahaya pada retina kemudian akan dihantarkan oleh nevus optikus ke kortek cerebri (Pearce, 2004).

Fungsi utama mata adalah untuk penglihatan Ketajaman penglihatan seseorang mungkin berbeda dengan orang lain. Tajam penglihatan tersebut merupakan derajad persepsi deteil dan kontour beda. Visus tersebut dibagi dua yaitu:

\section{Visus sentralis.}

Visus sentralis ini dibagi dua yaitu visus sentralis jauh dan visus sentralis dekat.

1. visus centralis jauh merupakan ketajaman penglihatan untuk melihat benda benda yang letaknyajauh. Pada keadaan ini mata tidak melakukan akomodasi

20 WARTA, Vol .10, No. 1, Maret 2007: 19 - 24 
2. virus centralis dekat yang merupakan ketajaman penglihatan untuk melihat benda benda dekat misalnya membaca, menulis dan lain lain. Pada keadaan ini mata harus akomodasi supaya bayangan benda tepat jatuh di retina.

\section{Visus perifer}

Pada visus ini menggambarkan luasnya medan penglihatan dan diperiksa dengan perimeter. Fungsi dari visus perifer adalah untuk mengenal tempat suatu benda terhadap sekitarnya dan pertahanan tubuh dengan reaksi menghindar jika ada bahaya dari samping.

Dalam klinis visus sentralis jauh tersebut diukur dengan menggunakan grafik huruf Snellen yang dilihat pada jarak 20 feet atau sekitar 6 meter. Jika hasil pemeriksaan tersebut visusnya e"20/20 maka tajam penglihatannya dikatakan normal dan jika Visus <20/20 maka tajam penglihatanya dikatakan kurang

Penyebab penurunan tajam peglihatan seseorang bermacam macam, salah satunya adalah refraksi anomaly/kelainan pembiasan. Beberapa kelaian refraksi anomaly tersebut adalah:

1. Hipermetrop

Pada keadaan ini penderita tidak bisa melihat dengan jelas obyek pada jarak dekat. Hal ini karena terlalu pendeknya bola mata atau terlalu lemahnya system lensa bila muskulus siliaris berelaksasi. Dalam keadaan ini berkas cahaya sejajar tidak cukup dibelokkan oleh system lensa sampai tepat di retina. Beberapa sebab dari hipermetrop tersebut adalah: axis antero-posterior trelalu pendek, kelainan posisi lensa dimana lensa bergeser ke belakang, curvature korne aterlalu datar dan index bias mata kurang dari normal. Sebagian besar penyebab hipermetrop ini adalah axis antero-posterior yang terlalu pendek sehingga bila di dapatkan hipermetrop pada anak anak ( $<25$ tahun) dengan nutrisi yang baik dapat berubah menjadi emetrop/normal.

Untuk mengoreksi mata hipermetrop ini perlu kaca mata lensa spheris (+).

\section{Miop/mata dekat}

Miop merupakan kebalikan dari hipermetrop, yaitu kurang jelas melihat obyek yang letaknya jauh. Hal ini terjadi karena panjangnya bola mata atau terlau besarnya kekuatan system lensa mata, sehingga berkas cahaya yang sejajar tidak cukup dibiaskan tepat di retina. Beberapa penyebab dari miop adalah axis mata terlalu pendek, lensa mata terlalu ke depan, indexs 
biasa terlalu besar dan kurvatura kornea terlalu cembung. Kelainan ini dapat dikoreksi dengan lensa spheris (-).

\section{Astigmatisme}

Astigmatisme merupakan kesalahan refraksi sitem lensa mata yang biasanya disebabkan oleh kornea yang berbentuk bujur atau lensa yang berbentuk bujur. Karena kelengkungan lensa astigmatisme disatu bidang lebih kecil dari bidang yang lain maka berkas cahaya yang mengenai bagian perifer lensa itu dalam satu bidang tidak bengkok sedemikian besar seperti berkas cahaya yang mengenai bagian perifer bidang lainnya Kelainan ini relatif jarang (Ganong,1995).

Astigmatisme dapat dikoreksi dengan lensa silindris.

\section{Presbiop}

Presbiop merupakan kelaianan akomodasi yang terjadi pada orang orang tua. Hal ini disebabkan lensa kehilangan elastisitasnya, sehingga daya lenting lensa berkurang yang menyebabkan lensa tidak bias memfokuskan bayangan benda yang berjarak dekat dengan mata. Kelainan ini dapat dikoreksi dengan menggunakan lensa cembung.

\section{HASIL DAN PEMBAHASAN}

Pada pengabdian masyarakat yang telah dilakukan pada bulan agustus 2006, tercatat sebanyak 31 siswa mengikuti pemeriksaan dan pelatihan. Pada pelatihan ini metode yang digunakan team mendemontrasikan cara pemeriksaan dengan memeriksa visus semua siswa kelas 5 SD tersebut.

Kemampuan siswa dalam mengikuti petunjuk pelatihan reatif sama dan tidak ada hambatan yang berarti

Dari hasil pemeriksaan yang bisa dilihat di lampiran 1 dapat dilihat bahwa terdapat 3 siswa yang memiliki visus kurang dari normal. Ketiga siswa tersebut memiliki mata miop, dimana siswa tersebut tidak kurang jelas melihat obyek/ tulisan yang jauh.

Hasilnya bias dilihat pada table 1 dibawah ini.

22 WARTA, Vol .10, No. 1, Maret 2007: 19 - 24 
Table 1.

Hasil Pemeriksaan Visus

\begin{tabular}{|l|l|l|l|l|}
\hline No & \multicolumn{1}{|c|}{ Nama } & Mata kanan & Mata kiri & \multicolumn{1}{|c|}{ Keterangan } \\
\hline 1 & Joko Susulo & Normal & $-0,5$ & Miop kiri \\
\hline 2 & Roni Aji Saputra & $-0,25$ & $-0,25$ & Miop kanan \&kiri \\
\hline 3 & Susi Rinasih & $-0,25$ & $-0,25$ & Miop Kanan \&kiri \\
\hline
\end{tabular}

Dari ke tiga siswa di atas semuanya menderita miop dimana siswa mengalami kekurangan tajam penglihatan untuk penglihatan jauh.

Beberapa hal yang diduga sebagai penyebab adalah: (1) kekurangan asupan gizi; (2) kekurangan vitamin A; dan (3) kekurangan pencahayaan di dalam kelas

Untuk mengantisipasi agar kerusakan mata tidak semakin parah maka pada ketiga orang tersebut disarankan: (1) merubah tempat duduknya dibagian depan dengan maksud agar mata tidak berakomodasi terus menerus yang akan menambah kerusakan mata; (2) meningkatkan asupan gizi dan vitamin terutama vitamin A; dan (3) kepada sekolah disarankan menambah penerangan dalam kelas

Pada pelatihan cara pemeriksaan, semua siswa dapat mengikuti dan mempraktekkan cara pemeriksaan visus dengan baik tanpa kesulitan yang berarti.

Untuk melakukan evaluasi keberhasilan pengabdian ini, team akan mengamati langsung cara pemeriksaan visus kelas 5 terhadap kelas 4 pada waktu akhir semester. Untuk mengetahui apakah saran yang anjurkan team kepada siswa dan guru kelasnya tersebut berdampak pada kemajuan siswa akan dilihat prestasinya terutama ketiga siswa yang mengalami miop tersebut dengan cara menanyakan langsung kepada wali kelasnya dan melihat nilai nilai ulangan atau rapor siswa tersebut pada akhir semester. 


\section{SIMPULAN DAN SARAN}

\section{a. Simpulan}

1. Terdapat 3 siswa yang memillki visus kurang dari normal dan semuaya menderita mata miop

2. Semua siswa kelas 5 bisa mengikuti dan mempraktekkan pelatihan pemeriksaan tajam penglihatan dengan baik tanpa hambatan yang berarti

\section{b. Saran}

Perlu dilakukan pelatihan cara pemeriksaan visus pada seluruh perwakilan SD yang dipusatkan di kecamatan.

\section{DAFTAR PUSTAKA}

Ganong. 1995. Fisiologi Kedokteran. 133-135, ed.14. Jakarta: EGC. Guyton. 2001. Fisiologi Manusia. 593-533, ed. 3. Jakarta: EGC.

Pearce. E. 2004. Anatomi \& Fisiologi untuk Paramedis. 314-32. Jakarta: Gramedia. 
Pelatihan Pemeriksaan ... (EM. Sutrisna, dkk.) 25 
26 WARTA, Vol .10, No. 1, Maret 2007: 19 - 24 
28 WARTA, Vol .10, No. 1, Maret 2007: 19 - 24 
